\title{
Role of Amyloid- $\beta$ Glycine 33 in Oligomerization, Toxicity, and Neuronal Plasticity
}

\author{
Anja Harmeier, ${ }^{1}$ Christian Wozny, ${ }^{2}$ Benjamin R. Rost, ${ }^{2}$ Lisa-Marie Munter, ${ }^{1}$ Haiqing Hua, ${ }^{3}$ Oleg Georgiev, ${ }^{3}$ \\ Michael Beyermann, ${ }^{4}$ Peter W. Hildebrand, ${ }^{5}$ Christoph Weise, ${ }^{1}$ Walter Schaffner, ${ }^{3}$ Dietmar Schmitz, ${ }^{2}$ \\ and Gerd Multhaup ${ }^{1}$ \\ ${ }^{1}$ Institut für Chemie und Biochemie, Freie Universität Berlin, Berlin 14195, Germany, ${ }^{2}$ Neurowissenschaftliches Forschungszentrum, Charité, Berlin 10117, \\ Germany, ${ }^{3}$ Institute of Molecular Biology, University of Zurich, Zurich 8057, Switzerland, ${ }^{4}$ Leibniz-Institut für Molekulare Pharmakologie, Berlin 13125, \\ Germany, and ${ }^{5}$ Institut für Medizinische Physik und Biophysik, Charité, Berlin 10117, Germany
}

The aggregation of the amyloid- $\beta(\mathrm{A} \beta)$ peptide plays a pivotal role in the pathogenesis of Alzheimer's disease, as soluble oligomers are intimately linked to neuronal toxicity and inhibition of hippocampal long-term potentiation (LTP). In the C-terminal region of $\mathrm{A} \beta$ there are three consecutive GxxxG dimerization motifs, which we could previously demonstrate to play a critical role in the generation of $A \beta$. Here, we show that glycine 33 (G33) of the central GxxxG interaction motif within the hydrophobic $A \beta$ sequence is important for the aggregation dynamics of the peptide. $A \beta$ peptides with alanine or isoleucine substitutions of $G 33$ displayed an increased propensity to form higher oligomers, which we could attribute to conformational changes. Importantly, the oligomers of $\mathrm{G} 33$ variants were much less toxic than $\mathrm{A} \beta_{42}$ wild type (WT), in vitro and in vivo. Also, whereas $\mathrm{A} \beta_{42}$ WT is known to inhibit LTP, $\mathrm{A} \beta_{42} \mathrm{G} 33$ variants had lost the potential to inhibit LTP. Our findings reveal that conformational changes induced by G33 substitutions unlink toxicity and oligomerization of $\mathrm{A} \beta$ on the molecular level and suggest that $\mathrm{G} 33$ is the key amino acid in the toxic activity of $\mathrm{A} \beta$. Thus, a specific toxic conformation of $A \beta$ exists, which represents a promising target for therapeutic interventions.

\section{Introduction}

The amyloid- $\beta(\mathrm{A} \beta)$ precursor protein (APP) is first cleaved by the $\beta$-site APP-cleaving enzyme and sequentially processed by the $\gamma$-secretase complex to generate $A \beta$ peptides of varying length (Qi-Takahara et al., 2005; Zhao et al., 2005). Especially $\mathrm{A} \beta_{42}$ molecules represent the main culprits in the pathogenesis of Alzheimer's disease (AD) (Younkin, 1998) as they were hypothesized to impair synaptic function and initiate neuronal degeneration (Simmons et al., 1994; Gong et al., 2003; Hsieh et al., 2006; Shankar et al., 2007). Soluble oligomers of amyloidogenic proteins are believed to be generically toxic; however, the precise biochemical mechanisms of toxicity are poorly understood (Bucciantini et al., 2002; Kayed et al., 2003). The pathogenic effects of $\mathrm{A} \beta$ are ascribed to the hydrophobic C-terminal stretch of 14 aa that is thought to be the seed for aggregation (Jarrett and Lansbury, 1993). Within this region, three repeat GxxxG motifs encompassing $A \beta$ residues $G 25$ to $G 37$ promote $A \beta_{42}$ aggregation independent from the identity of the hydrophobic residues in the $\mathrm{x}$-positions (Kim and Hecht, 2006).

The glycines of the central GxxxG motif (see Fig. 1A) were discovered as key amino acids that stabilize the association of the $\alpha$-helices of APP transmembrane dimers (Munter et al., 2007).

\footnotetext{
Received March 19, 2009; revised April 30, 2009; accepted May 8, 2009.

This work was supported by the Deutsche Forschungsgemeinschaft and the Hans und Ilse Breuer Stiftung.

Correspondence should be addressed to Gerd Multhaup, Institut für Chemie und Biochemie, Freie Universität

Berlin, Thielallee 63, 14195 Berlin, Germany. E-mail: multhaup@biochemie.fu-berlin.de.

C. Wozny's present address: MRC Laboratory of Molecular Biology, Cambridge CB2 3EB, UK.

DOI:10.1523/JNEUROSCI.1336-09.2009

Copyright $\odot 2009$ Society for Neuroscience $\quad$ 0270-6474/09/297582-09\$15.00/0
}

The residues G29 and G33 of the helix interface affect the generation of $\mathrm{A} \beta$ by modulating $\gamma$-secretase complex activity (Munter et al., 2007; Kienlen-Campard et al., 2008).

In $A \beta$ peptides, the GxxxG motif has a different role with a major impact on aggregation (Liu et al., 2005; Sato et al., 2006). Substitution of G33 or G37 to leucines prevented $A \beta_{40}$ fibrillization and destabilized the fibril structure by disrupting the glycine-zipper-packing interface (Kim et al., 2005; Sato et al., 2006). Similarly, glycine to leucine substitutions of synthetic peptides were described to decrease the level of dimers and trimers in solution and caused a reduced toxicity as well as a reduced avidity to bind lipid membranes (Hung et al., 2008). A gradually decreasing cellular toxicity compared with the wild-type form was suggested to depend on membrane permeabilization of peptides with nonconservative glycine to leucine substitutions in the order G29L $>$ G33L $\geq$ G37L (Kim et al., 2005).

In this study, we show that $\mathrm{G} 33$ represents the critical residue for the assembly of $\mathrm{A} \beta_{42}$ into neurotoxic aggregates by using individual glycine substitutions to alanine or to isoleucine. Unlike $\mathrm{A} \beta_{42}$ wild-type (WT) peptides, substitutions of $\mathrm{G} 33$ of the central GxxxG motif promoted rapid oligomerization through a conformational change. Furthermore, treatment of neuronal cultures with natively purified oligomers and the expression of the different $A \beta$ mutants in the Drosophila melanogaster eye demonstrated that G33 is the critical residue that mediates toxicity in vitro and in vivo. Although $\mathrm{A} \beta_{42}$ WT potently inhibits long-term potentiation (LTP), oligomers derived from $\mathrm{A} \beta_{42}$ G33 substitution peptides are unable to impair synaptic plasticity. Thus, toxicity of $\mathrm{A} \beta$ is not a simple effect of oligomerization but a conse- 


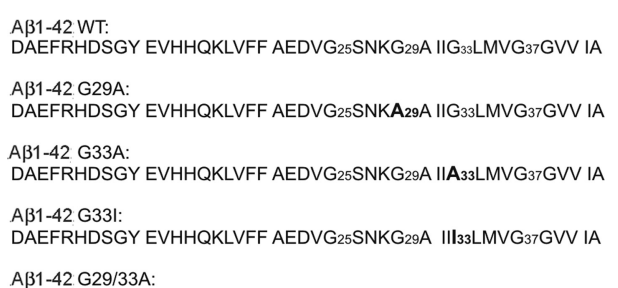

A 1 1-42 G29/33A:

DAEFRHDSGY EVHHQKLVFF AEDVG 25 SNKA 29 A $\|$ A $_{33}$ LMVG $_{37} G V V$ IA
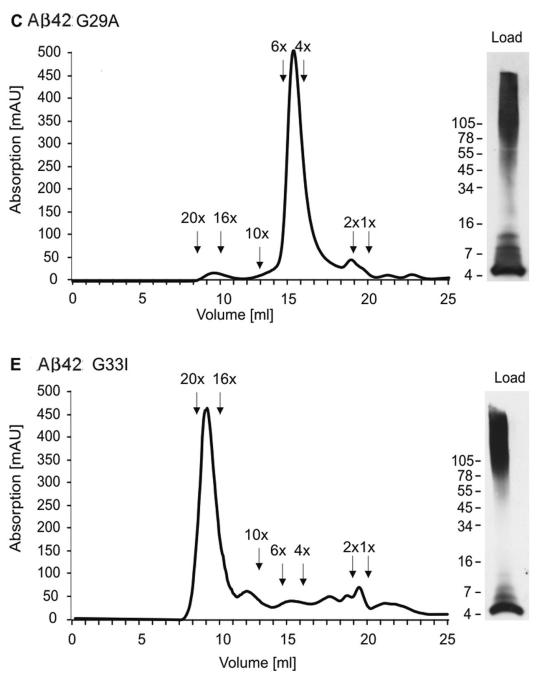
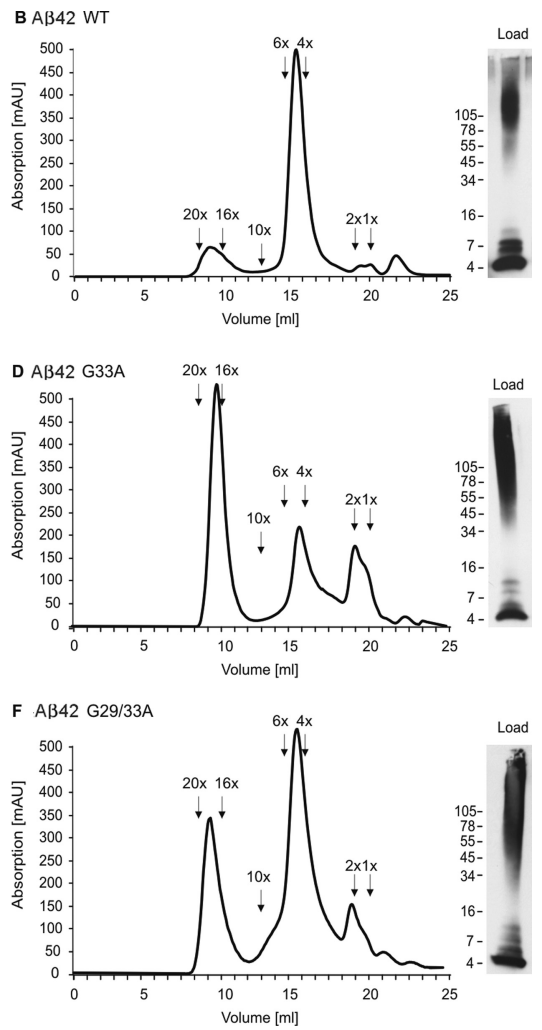

Figure 1. Single amino acid exchanges within the $G x x \in$ motif of $A \beta_{42}$ modulate oligomerization. $A$, Amino acid sequence of $A \beta_{1-42}$ with the glycines of the three consecutive GxxxG motifs numbered. The amino acid substitutions of the analyzed central GxxxG motif are in bold. $\boldsymbol{B}-\boldsymbol{F}$, SEC and Western blot analysis of freshly dissolved synthetic $A \beta_{42}$ peptides. $\boldsymbol{B}, A \beta_{42}$ WT peptides preferentially form tetramers but also lower and higher oligomers. $C, A \beta_{42} G 29 A$ peptides preferentially form tetramers and only few other oligomers. $\boldsymbol{D}, A \beta_{42} \mathrm{G} 33 \mathrm{~A}$ variant peptide mainly form higher oligomers but also low- $n$ oligomers. $\boldsymbol{E}, A \beta_{42} G 33$ I substitution peptides almost exclusively form higher oligomers but hardly any monomers to decamers. $\boldsymbol{F}$, Size separation of $A \beta_{42}$ $\mathrm{G} 29 / 33 \mathrm{~A}$ yields high amounts of tetramers but also large amounts of high oligomers. Representative chromatograms of at least three independent measurements are shown. Western blots of freshly dissolved synthetic $A \beta$ aggregates (Load) (compare figure insets) in the presence of SDS reveal monomers and high- $n$ oligomers for all peptides. Compared with A $\beta_{42}$ WT, G29A, and $\mathrm{G} 29 / 33 \mathrm{~A}$, solely the amount of low- $n$ oligomers of $A \beta_{42} \mathrm{G} 33$ substitution peptides is reduced.

quence of a G33-driven conformation rendering $A \beta$ oligomers toxic.

\section{Materials and Methods}

Peptides. Peptides were synthesized as described previously (Beyermann et al., 1996; Kaden et al., 2008) and verified by matrix-associated laser desorption ionization-mass spectrometry (MALDI-MS; Ultraflex-II TOF/TOF, Bruker Daltonics). Briefly, peptides were synthesized at automated synthesizer (ABI 433a; Applied Biosystems) on Trt-Tentagel resin [Rapp-Polymere (0.25 $\mathrm{mmol} / \mathrm{g}, 0.5 \mathrm{~g}$ ) using $\mathrm{N}$-(9-fluorenyl)methoxycarbonyl(Fmoc)-strategy (double couplings with 9 equivalents of Fmoc-aa/2-(1H-benzotriazole-1-yl)-1,1,3,3tetra-methyluronium hexafluorophosphate/6 equivalents of $\mathrm{N}, \mathrm{N}$-diisopropylethylamine]. After final cleavage and deprotection using trifluoroacetic acid/ $\mathrm{H}_{2} \mathrm{O}(9 / 1)$, crude peptides were purified by preparative RP-HPLC to give final products of $95 \%$ purity according to HPLC analysis (detector $220 \mathrm{~nm}$ ). To monomerize synthetic $\mathrm{A} \beta$ before size-exclusion chromatography (SEC), peptides were dissolved in $98 \%$ formic acid yielding an average ratio of monomers:dimers:trimers of 55:30:15 (Roher et al., 1996). After immediate evaporation of the solvent, peptides were dissolved to $1 \mathrm{mg} / \mathrm{ml}$ in $0.1 \%$ ammonia in water (Schmechel et al., 2003). For detection of A $\beta$ peptides by Western blot, we added $4 \times$ sample buffer to the samples and electrophoresed untreated or for $3 \mathrm{~min}$ at $95^{\circ} \mathrm{C}$ heated samples on $10-20 \%$ Tris-tricine gels (Anamed) according to the manufacturer's instructions. Proteins were transferred on $0.2 \mu$ m nitrocellulose, and $\mathrm{A} \beta$ was detected by Western blot analysis after incubation of the filter with 2 $\mu \mathrm{g} / \mathrm{ml}$ W0-2 antibody (The Genetics Company). Different batches of A $\beta$ peptides were used to exclude individual differences which were not observed through out all studies.
SEC. For size-exclusion chromatography, a Superdex 75 (10/30HR) column (GE Healthcare) was used. Aliquots of 0.5 to $1 \mathrm{mg}$ synthetic peptide prepared as previously described (Roher et al., 1996; Schmechel et al., 2003) were loaded, and $1 \mathrm{ml}$ fractions were eluted with $1 \times$ PBS (137 mM NaCl, $2.7 \mathrm{~mm} \mathrm{KCl,} 10 \mathrm{~mm}$ $\mathrm{Na}_{2} \mathrm{HPO}_{4}, 2 \mathrm{~mm} \mathrm{KH} \mathrm{PO}_{4}$ ) at a flow rate of 0.5 $\mathrm{ml} / \mathrm{min}$. Peptide concentrations were determined by BCA assay. The collected fractions were immediately used for subsequent experiments. The aggregation states of oligomers, separated under native conditions, were further analyzed by SDS-PAGE under denaturing and reducing conditions by Western blot studies using the W0-2 antibody (The Genetics Company).

Limited proteolysis. Peptides were dissolved in $25 \mathrm{~mm}$ ammonium bicarbonate, $\mathrm{pH} 7.5$ at a concentration of $20 \mu \mathrm{g} / \mathrm{ml}$. The tryptic digest was performed at $37^{\circ} \mathrm{C}$ using an enzyme-substrate ratio of 1:500 trypsin (Roche) for up to $3 \mathrm{~h}$. Fragments were identified by MALDI-MS (Ultraflex-II TOF/TOF; Bruker Daltonics) with sinapinic acid as matrix.

Modeling. The structure of the $\mathrm{A} \beta_{42} \mathrm{WT}$ tetramer and variant peptides were modeled using the nuclear magnetic resonance structure of $\mathrm{A} \beta_{1-42}$ fibrils (pdb-entry: 2beg) as a template (Lührs et al., 2005). All peptides were energetically minimized with help of the GROMOS 43B1 force field to avoid distorted geometries (Christen et al., 2005). Electrostatic surface potentials were calculated using the program APBS (adaptive Poisson-Boltzman solver) (Sanner et al., 1996) with nonlinear PoissonBoltzmann equation and contoured at $\pm 9 \mathrm{kT} / \mathrm{e}$.

Toxicity of $A \beta_{42}$ on neuroblastoma cells. SHSY5Y cells were routinely cultured in DMEM/ Ham's-F12 medium (PAA) supplemented with $10 \%(\mathrm{v} / \mathrm{v})$ bovine calf serum, $2 \mathrm{~mm}$ glutamine, $0.1 \mathrm{~mm}$ nonessential amino acids, $100 \mathrm{U} / \mathrm{ml}$ penicillin and $10 \mu \mathrm{g}$ streptomycin, and $0.5 \mathrm{~mm}$ sodium pyruvate in a $5 \%$ $\mathrm{CO}_{2}$-humidified atmosphere at $37^{\circ} \mathrm{C}$. After $48 \mathrm{~h}$, medium was replaced by medium containing freshly dissolved peptides or SEC fractions and incubated for $12 \mathrm{~h}$. Reduction of 3-(4,5-dimethylthiazol-2-yl)-2,5diphenyltetrazolium bromide (MTT) was used to monitor $\mathrm{A} \beta$ toxicity. MTT stock solution $(5 \mathrm{mg} / \mathrm{ml})$ was diluted 1:10 and incubated for another 1-2 h. Cells were lysed with DMSO, and the absorbance of blue formazan at $562 \mathrm{~nm}$ was measured using an automatic microplate reader. In addition, toxicity was analyzed using 3-(4,5-dimethylthiazol-2-yl)-53-carboxymethoxy-phenyl)-2-(4-sulfophenyl)-2 $H$-tetrazolium (MTS) assay (Promega), according to the manufacturer's instructions.

Toxicity of $A \beta_{42}$ on primary hippocampal neurons. Hippocampi of postnatal day 0 (P0)-P1 Wistar rat pups were dissociated with papain and cultured in neurobasal A medium supplemented with 2\% B27, 2 mM glutamax, and $0.2 \%$ penicillin/streptomycin on glia cell feeder layers. After $10 \mathrm{~d}$ in vitro, neuronal cultures were treated with $\mathrm{A} \beta_{1-42}$ freshly dissolved or with SEC fractions for another $48 \mathrm{~h}$. Neuronal viability was detected using the MultiTox-Fluor Multiplex Cytotoxicity assay (Promega), performed according to manufacturer's instructions.

Drosophila melanogaster transformation and eye structure analysis. The $\mathrm{A} \beta_{42}$-coding sequence preceded by the signal-peptide sequence of Drosophila Hedgehog protein was ligated into the P-element transformation vector $\mathrm{pUAST}$ yielding the construct $\mathrm{PUAST}-\mathrm{SP}-\mathrm{A} \beta_{42}$ WT. Mutations were generated using the quick-change mutagenesis technique. pUAST-SP-A $\beta_{42}$, pUAST-SP-A $\beta_{42}$ G29/33A, and pUAST-SP-A $\beta_{42}$ G33I constructs were used to generate transgenic flies with standard P-element-mediated transformation. Transgenic flies harboring UAS- 
$\mathrm{A} \beta_{42}$ WT or UAS $-\mathrm{A} \beta_{42}$ G29/33A or UAS $-\mathrm{A} \beta_{42}$ G33I were crossed with flies containing GMRGal4 (glass multimer reporter) to achieve eyespecific expression of $A \beta$ peptides. Five-dayold flies were collected and analyzed. Scanning electron microscopy pictures were taken with a JEOL JSM-6360LV microscope. Eye sections were analyzed as described previously (Basler and Hafen, 1988).

Electrophysiology. For electrophysiological measurements, hippocampal slices from 3- to 6-week-old Wistar rats were prepared and stored in oxygenated artificial CSF (ACSF; 119 mм NaCl, 1 mм NaH${ }_{2} \mathrm{PO}_{4}, 10 \mathrm{~mm}$ glucose, 1.3 mм $\mathrm{MgSO}_{4}, 2.5 \mathrm{~mm} \mathrm{CaCl}_{2}, 2.5 \mathrm{~mm} \mathrm{KCl,} 26 \mathrm{~mm}$ $\mathrm{NaHCO}_{3}$ ). Field EPSPs (fEPSPs) were recorded in stratum radiatum of area CA1 and evoked by Schaffer collateral stimulation with ACSF-filled electrodes. For the measurement of two independent pathways, two stimulating electrodes were positioned in parallel to each other. Baseline responses were collected using test pulses that yield $30-40 \%$ of the maximal fEPSP slope. Stable baseline response was measured for at least $10 \mathrm{~min}$, slices were supplied with $500 \mathrm{~nm}$ peptide $20 \mathrm{~min}$ before tetanization. LTP was induced by theta-burst stimulation (TBS) of one of the two pathways. The intertheta burst stimulation interval was $20 \mathrm{~s}$, and four TBSs were applied to induce LTP. TBS consisted of 10 bursts delivered at $5 \mathrm{~Hz}$. Each burst consisted of four pulses delivered at $100 \mathrm{~Hz}$. After TBS, fEPSPs were observed for $30 \mathrm{~min}$. The amount of LTP was described as percentage changes of fEPSP slopes after TBS normalized to baseline values with an additional subtraction of the second, unstimulated pathway. Slopes were analyzed using IGOR (Wavemetrics).

\section{Results}

\section{Substitution of amino acid residue G33 of the GxxxG motif provokes $A \boldsymbol{\beta}$ aggregation}

We investigated the role of glycine residues within the GxxxG motif in $\mathrm{A} \beta$ oligomerization by SEC using synthetic $\mathrm{A} \beta_{42}$ peptides with substitutions of G29 and G33 to alanine or isoleucine (Fig. 1A). We found similar elution patterns for $\mathrm{A} \beta_{42} \mathrm{WT}$ (Fig. $1 B$ ) and $\mathrm{A} \beta_{42}$ G29A (Fig. $1 C$ ). The fractions primarily yielded tetramers and hexamers and only minor amounts of oligomers corresponding to apparent molecular masses of 16- to 20-mers, dimers, and monomers (Fig. $1 B, C$ ). In contrast, single amino acid substitutions at position $\mathrm{G} 33$ resulted in a dramatic increase in the relative amount of higher oligomers (16- to 20-mers) at the expense of lower oligomers (2- to 4-mers) (Fig. 1D,E), depending on the increasing hydrophobicity of the substituted amino acid at this position in the order $\mathrm{WT}<\mathrm{G} 33 \mathrm{~A}<\mathrm{G} 33 \mathrm{I}$. Finally, the double substitution $\mathrm{A} \beta_{42}$ G29/33A yielded an intermediate oligomerization with similar amounts of 16- to 20-mers and 4- to 6-mers (Fig. $1 F$ ). Thus, G33 plays a critical role in early aggregation of $\mathrm{A} \beta_{42}$ into higher oligomers, whereas G29 has no effects. Subsequently, the oligomeric distribution was confirmed by Western blot analysis of the respective SEC fractions (supplemental Fig. S1, available at www.jneurosci.org as supplemental material), although the presence of SDS caused a partial dissociation of the aggregates into monomers. Thus, using different techniques, we found that G33 substitutions rather promoted than retarded the aggregation process, implying that G33 is a key residue during the early steps of oligomerization.

\section{Aggregation characteristics of $A \boldsymbol{\beta}_{42} \mathrm{G} 33$ variants are determined by conformational changes}

To examine whether the observed differences in aggregation behavior are attributable to differences in oligomer folding, we used limited trypsin proteolysis coupled to mass spectrometry (Fig. 2). Proteolysis leads to the production of fragments $\mathrm{A} \beta_{1-16}$ (data not shown), $\mathrm{A} \beta_{1-28}$, and the corresponding $\mathrm{C}$-terminal products implying that this region is highly flexible and easily accessible for trypsin (Fig. 2). The representative spectra of all peptides tested reveal that after a $3 \mathrm{~h}$ digest with trypsin, the fragment $\mathrm{A} \beta_{17-42}$ was generated from $\mathrm{A} \beta_{42}$ (Fig. $2 A$ ). At this time point, the generation of the fragment $A \beta_{1-28}$ was impaired for the G33 single substitution peptides compared with the three other peptides. In a time course analysis of the proteolysis, the ratio of peak areas of fragment $\mathrm{A} \beta_{1-28}$ to uncleaved $\mathrm{A} \beta_{42}$ was calculated. In case of $\mathrm{A} \beta_{42}$ G29A and $\mathrm{A} \beta_{42} \mathrm{G} 29 / 33 \mathrm{~A}$, we observed a time-dependent generation of the fragment $\mathrm{A} \beta_{1-28}$ during the $3 \mathrm{~h}$ period of digestion with an increased ratio of $\mathrm{A} \beta_{1-28} / \mathrm{A} \beta_{42}$ compared with $\mathrm{A} \beta_{42}$ WT (Fig. $2 B$ ). In contrast, $A \beta_{42}$ G33A and $A \beta_{42}$ G33I peptides remained virtually uncleaved at position K28 (Fig. $2 C$ ). Thus, $\mathrm{A} \beta_{42}$ G29A and G29/33A peptides seemingly possess a more open conformation compared with $\mathrm{A} \beta_{42}$ WT. Whereas single and double substitutions including G29 promote a conformation that is better accessible to trypsin, the single substitutions of G33 to alanine or isoleucine rather induce a more tightly packed conformation, thereby masking K28. As a conclusion, the different accessibility of K28 to trypsin indicates that the G33 substitution further enhances the stability of the folding nucleus around this lysine residue within the turn region (Lazo et al., 2005; Grant et al., 2007). Hence, G33 can be regarded as a key residue to drive the intermolecular peptide interactions, which is necessary for higher-order peptide assembly.

\section{Conformational changes of $\mathrm{A} \boldsymbol{\beta}_{42} \mathrm{G} 33$ variants are induced by increased hydrophobicity}

In a computational analysis of $\mathrm{A} \beta_{42} \mathrm{WT}$ and substitution peptides, the modeling illustrates that, in contrast to the WT peptide 
A

$\mathrm{AB42}$ wt

D...VG $25 \mathrm{SNKG}_{29}$ AllG $33 \mathrm{LMVG}_{37} \mathrm{GV}$ VIA
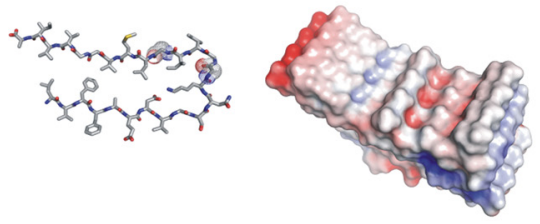

C

AB42 G33A

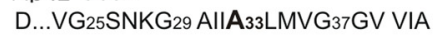

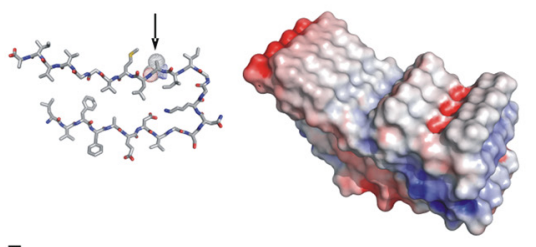

E

A 342 G29/33A

D...VG $25 S N K A_{29}$ AllA ${ }_{33} L_{M V G}{ }_{37} G V$ VIA

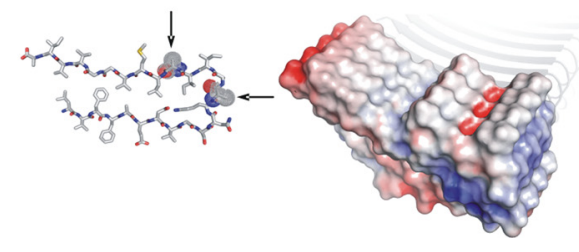

Figure 3. Single amino acid exchange at position $G 33$ modifies conformation of $A \beta_{42}$ oligomers. Amino acid sequences and computational models of $A \beta_{42}$ WT $(\boldsymbol{A}), A \beta_{42} G 29 A(\boldsymbol{B}), A \beta_{42} G 33 A(\boldsymbol{C}), A \beta_{42} G 331(\boldsymbol{D})$, and $A \beta_{42} G 29 / 33 A(\boldsymbol{E})$ monomers and tetramers. Glycine residues $25,29,33$, and 37 of the three consecutive $\mathrm{GxxxG}$ motifs are numbered, and substitutions at position G29 and G33 are in bold (sequence) and with arrows (monomer model). Negatively charged surfaces in red, positively charged in blue (Baker et al., 2001). Increase in hydrophobicity at G33 leads to stabilization of the folding core, provokes $\beta$-sheet conformation and increases oligomerization.

(Fig. 3A), a continuous hydrophobic surface is formed by G33 substitution (Fig. $3 C$ ). This effect is even more pronounced for the G33I substitution (Fig. 3D). When the peptides assemble into $\beta$-sheets, the hydrophobic side chains of G33I and G33A are effectively shielded from the polar milieu (Fig. 3C,D; supplemental Fig. S2, available at www.jneurosci.org as supplemental material). Simultaneously, the hydrophobic side chains of the neighboring hydrophobic residues I31 and/or M35 are also buried, which might explain why $\mathrm{A} \beta_{42} \mathrm{G} 33 \mathrm{~A}$ and G33I peptides are tightly packed, masking $\mathrm{K} 28$ and tend to form higher oligomers compared with $\mathrm{A} \beta_{42}$ WT (supplemental Fig. S2, available at www. jneurosci.org as supplemental material). In contrast, G29 is positioned within the turn structure of $\mathrm{A} \beta_{42}$, and its side chain is entirely exposed, offering an explanation why the G29A substitution has only a weak effect on oligomerization and why it can be cleaved more effectively by trypsin (Figs. 1, 2, 3B; supplemental Fig. S2, available at www.jneurosci.org as supplemental material). Interestingly, the double substitution peptide $A \beta_{42} G 29$ / $33 \mathrm{~A}$ yields an intermediate state (Fig. 3E; supplemental Fig. S2, available at www.jneurosci.org as supplemental material), also in terms of oligomerization (Fig. $1 F$ ), which is attributable to the change in the turn structure induced by G29A and the continuous hydrophobic surface, which can be allocated to the G33A substitution. This suggests a close interplay of G29 and G33 of the central GxxxG motif that plays a crucial role in the folding of $\mathrm{A} \beta_{42}$.

\section{$\mathrm{A} \boldsymbol{\beta}$ toxicity is determined by $\mathrm{G} 33$}

To examine the toxic properties of $\mathrm{A} \beta_{42} \mathrm{WT}$ or the substitution peptides, we tested the effects of a freshly dissolved mixture or defined SEC fractions on the cell death of human neuroblastoma SH-SY5Y cells using MTT and MTS assays and on primary neurons using the MultiTox assay (Figs. 4, 5). Treatment of SH-SY5Y cells with equal aliquots of crude $\mathrm{A} \beta_{42}$ WT peptide [corresponding to "Load" fractions of SEC (Fig. $1 B)]$ reduced the number of living cells by $59 \pm 7 \%$ compared with untreated cells (Fig. 4A). When we analyzed different defined oligomeric SEC fractions, tetramers of $\mathrm{A} \beta_{42}$ WT exhibited the highest toxicity. Interestingly, toxicity negatively correlated with samples containing oligomers higher than tetramers (Fig. 4A). Because of the relatively limited power of separation by SEC and because of broad fractions collected, we observed toxicity in samples that mainly contained monomers but most likely also contaminating dimers (supplemental Fig. S1, available at www. jneurosci.org as supplemental material).

On primary cultures of hippocampal neurons, fractions containing low- $n \mathrm{~A} \beta_{42}$ WT oligomers were found to be most toxic (Fig. 5A). Similar to the $\mathrm{A} \beta_{42}$ WT peptides, tetramers of $A \beta_{42}$ G29A induced highest toxic effects on SH-SY5Y cells and on primary neurons. Toxicity was stepwise declining when oligomerization proceeded (Figs. $4 B, 5 B$ ). In sharp contrast, in none of the fractions containing $A \beta_{42}$ G33A or $\mathrm{A} \beta_{42}$ G33I a significant level of toxicity was detected, neither on neuroblastoma cells nor on primary neurons (Figs. $4 C, D, 5 C, D$ ). Solely, $\mathrm{A} \beta_{42} \mathrm{G} 29 / 33 \mathrm{~A}$ demonstrated an intermediate toxicity compared with $\mathrm{A} \beta_{42}$ WT and $\mathrm{A} \beta_{42}$ G33 single substitution peptides (Figs. 4, 5A,D,E).

In an additional approach, we used Drosophila melanogaster flies where $A \beta$ toxicity is evident from a range of eye abnormalities (Finelli et al., 2004), and the extent of cell death can be determined by visual inspection of the eye structure (Basler and Hafen, 1988). Therefore, to further investigate the toxicity of mutations within the central GxxxG motif in vivo, we generated and selected strains expressing equal amounts of secreted $A \beta_{42}$ WT, $A \beta_{42}$ G29/33A, or $\mathrm{A} \beta_{42}$ G33I in the eye (Fig. 6; supplemental Fig. S3, available at www. jneurosci.org as supplemental material). Compared with nontransgenic control animals, analysis of eye sections from transgenic flies demonstrated that $\mathrm{A} \beta_{42}$ G33I induces a very mild toxic effect, which is evident from a weak distortion in eye morphology (Fig. 6A,D). In contrast, $\mathrm{A} \beta_{42}$ WT or $\mathrm{A} \beta_{42} \mathrm{G} 29 / 33 \mathrm{~A}$ mutants both caused severe eye degeneration (Fig. $6 B, C$ ). Toxicity can be estimated as a ratio of rhabdomeres to ommatidia, which we found significantly reduced for $\mathrm{A} \beta_{42}$ WT and $\mathrm{A} \beta_{42}$ G29/33A mutants compared with control animals (Fig. $6 E$ ). Conversely, $A \beta_{42}$ G33I flies exhibited a ratio of rhabdomeres to ommatidia that was not significantly different from the control flies (Fig. 6E), although the visual inspection indicates a slight change in morphology. Additionally, whereas treatment with the double substitution peptide $\mathrm{A} \beta_{42}$ G29/33A revealed an intermediate characteristic of toxicity on the two different cell culture systems analyzed, toxicity in the Drosophila model of the $\mathrm{A} \beta_{42} \mathrm{G} 29 / 33 \mathrm{~A}$ mutant strongly resembles the situation in the $\mathrm{A} \beta \mathrm{WT}$ expressing fly strain. The GMR regulatory region is known to drive expression of a linked gene from late larval stage throughout adult life. Most likely 
the observed eye phenotypes have a developmental as well as a continued expression component, and the toxic effect of $\mathrm{A} \beta_{42}$ G29/33A would reflect an in vivo situation that differs from the effects of synthetic peptides on mature SH-SY5Y cells or primary neurons.

\section{A $\beta$ inhibition of LTP is determined by $\mathrm{G} 33$}

Hippocampal LTP is a form of synaptic plasticity thought to correlate with learning and memory formation on a cellular level. Maintenance of hippocampal LTP is inhibited by synthetic and natural soluble $\mathrm{A} \beta$ oligomers, principally dimers and low- $n$ oligomers (Walsh et al., 2002; Wang et al., 2002; Klyubin et al., 2005; Cheon et al., 2007; Klyubin et al., 2008). LTP is also inhibited by $\mathrm{A} \beta$ peptides of shorter sequence with a biological activity being attributed to the region encompassing residues 25-35 (Freir et al., 2003; Gengler et al., 2007) containing G29 and G33 of the $\mathrm{A} \beta$ GxxxG motif. To test whether G33 is crucial for the abolishment of LTP by $\mathrm{A} \beta_{42}$, we assessed the effect of $\mathrm{A} \beta_{42} \mathrm{GxxxG}$ substitution peptides on theta burstinduced LTP in the CA1 region of rat hippocampal slices. As expected, $\mathrm{A} \beta_{42} \mathrm{WT}$ inhibited LTP compared with control conditions (Fig. $7 A, D$ ). In contrast, the G33I substitution of $\mathrm{A} \beta_{42}$ peptides did not inhibit LTP but was comparable with control slices, when a solution of freshly dissolved $\mathrm{A} \beta_{42}$ G33I peptides was tested (control vs $\mathrm{A} \beta_{42} \mathrm{G} 33 \mathrm{I}$ ) (Fig. $7 \mathrm{~B}, \mathrm{D}$ ). Since $\mathrm{A} \beta_{42}$ G33I only yielded very minor amounts of tetramers (Fig. $1 E$ ), we tested SEC fractions containing $A \beta_{42}$ G33A tetramers on LTP inhibition. Unlike $\mathrm{A} \beta_{42}$ WT which inhibited LTP, $A \beta_{42}$ G33I and tetramers formed by $\mathrm{A} \beta_{42}$ G33A (Fig. $7 C, D)$ substitution peptides had no effect on LTP. Thus, our results reveal that the aggregation of $\mathrm{A} \beta_{42}$ into tetramers does not necessarily inhibit LTP.

\section{Discussion}

The progressive neurodegenerative symptoms of $\mathrm{AD}$ are at the earliest evident by cumulative deficits in learning and memory. In vivo, this loss in cognitive functions correlates with a decrease in synaptic markers and appears long before $\mathrm{A} \beta$ plaque deposition is detected (Hsia et al., 1999; Moechars et al., 1999; Mucke et al., 2000; Spires et al., 2005). Despite the evidence that low- $n$ A $\beta$ oligomers can interfere with normal synaptic physiology (Podlisny et al., 1995; Shankar et al., 2008), it remains an unanswered question if $\mathrm{A} \beta$ oligomers contribute to the cognitive decline in $\mathrm{AD}$. Little is known about the factors that regulate the generation of toxic $\mathrm{A} \beta$ aggregates in the aging brain. The production of soluble oligomeric intermediates of $A \beta$ was early discovered to be responsible for $A \beta$ toxicity and LTP inhibition (Yankner et al., 1989; Stern et al., 2004), whereas larger A $\beta$ fibrils
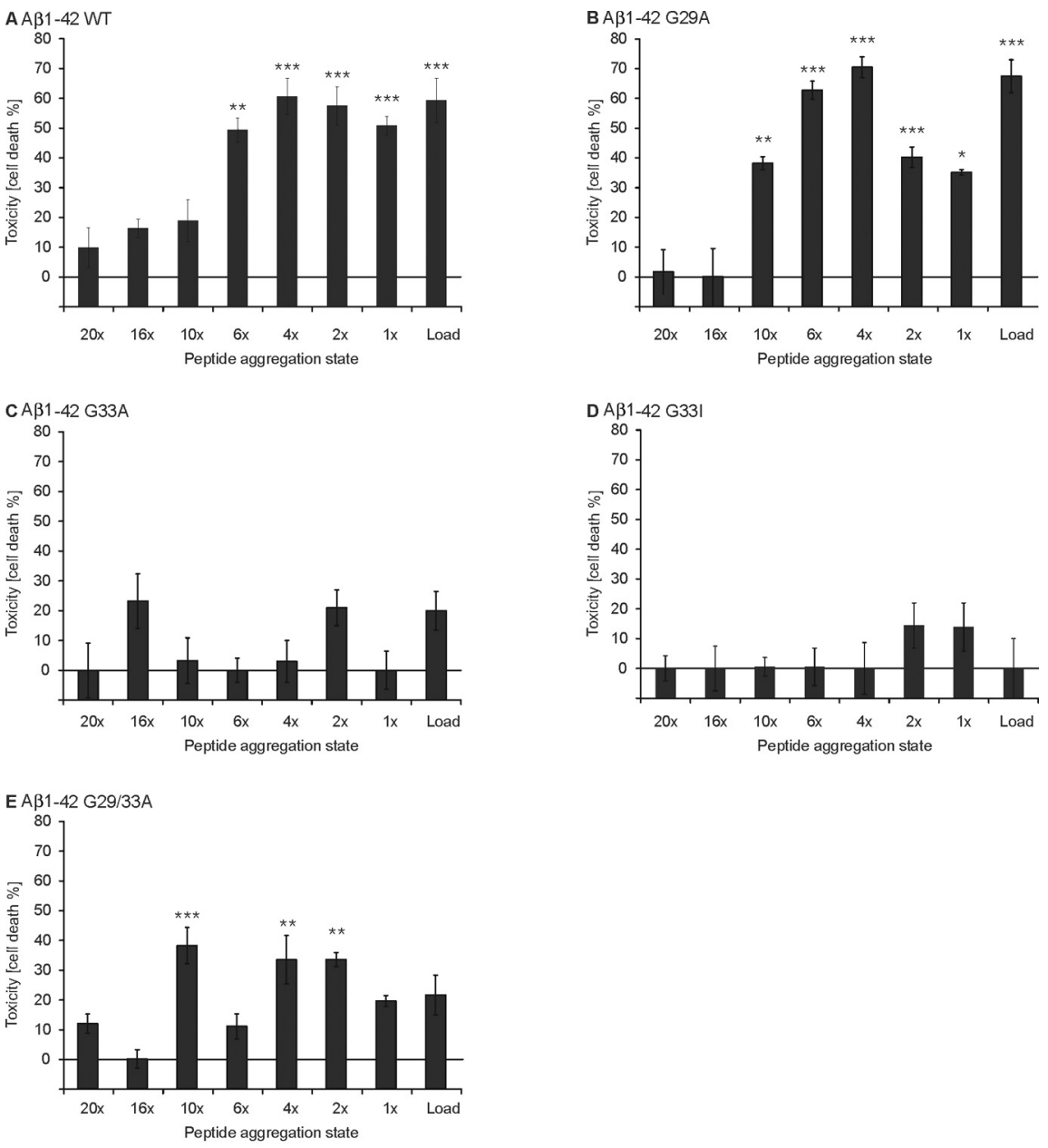

Figure 4. $A \beta_{42}$ WT but not $A \beta_{42} G 33$ substitution peptides are toxic to neuroblastoma cells. For all measurements, equal amounts of freshly dissolved peptides (Load) or of oligomer fractions after SEC and as determined by the BCA assays were used. A reveals toxicity similar to the WT peptide. $\boldsymbol{C}, \boldsymbol{D}$, Both $A \beta_{42} \mathrm{G} 33 \mathrm{~A}(\boldsymbol{C})$ and $A \beta_{42} \mathrm{G} 33 \mathrm{I}(\boldsymbol{D})$ lack any significant toxicity. $\boldsymbol{E}_{2}$ in
42 $\left.0.01,{ }^{* *} p<0.001,{ }^{* * *} p<0.0001\right)$.

were inert (Podlisny et al., 1995; Roher et al., 1996, 2000; McLean et al., 1999; Walsh et al., 2002; Roychaudhuri et al., 2009). Nevertheless, amyloid plaque fibrils were recently shown to represent potentially major sources of soluble toxic $\mathrm{A} \beta$ aggregates when they are activated by exposure to biological lipids (Martins et al., 2008). Amyloid fibrils once resolubilized to oligomers thus became highly toxic (Martins et al., 2008).

Although it has been demonstrated that $\mathrm{A} \beta$ oligomerization is a key step in the toxicity, we provide evidence that a single amino acid residue (G33) of the GxxxG motif is a key residue influencing toxicity of $\mathrm{A} \beta_{42}$ enabling now to better define the origin of toxicity.

Earlier reports have shown that nonconservative substitutions of glycines to leucines effect toxic behavior in vitro of a crude mixture of $\mathrm{A} \beta_{42}$ peptides (Kim et al., 2005; Hung et al., 2008). In this study, we have determined by conservative and nonconservative substitutions of the GxxxG motif that G33 of $A \beta$ is the critical residue for peptide aggregation, in vivo toxicity in neuro- 

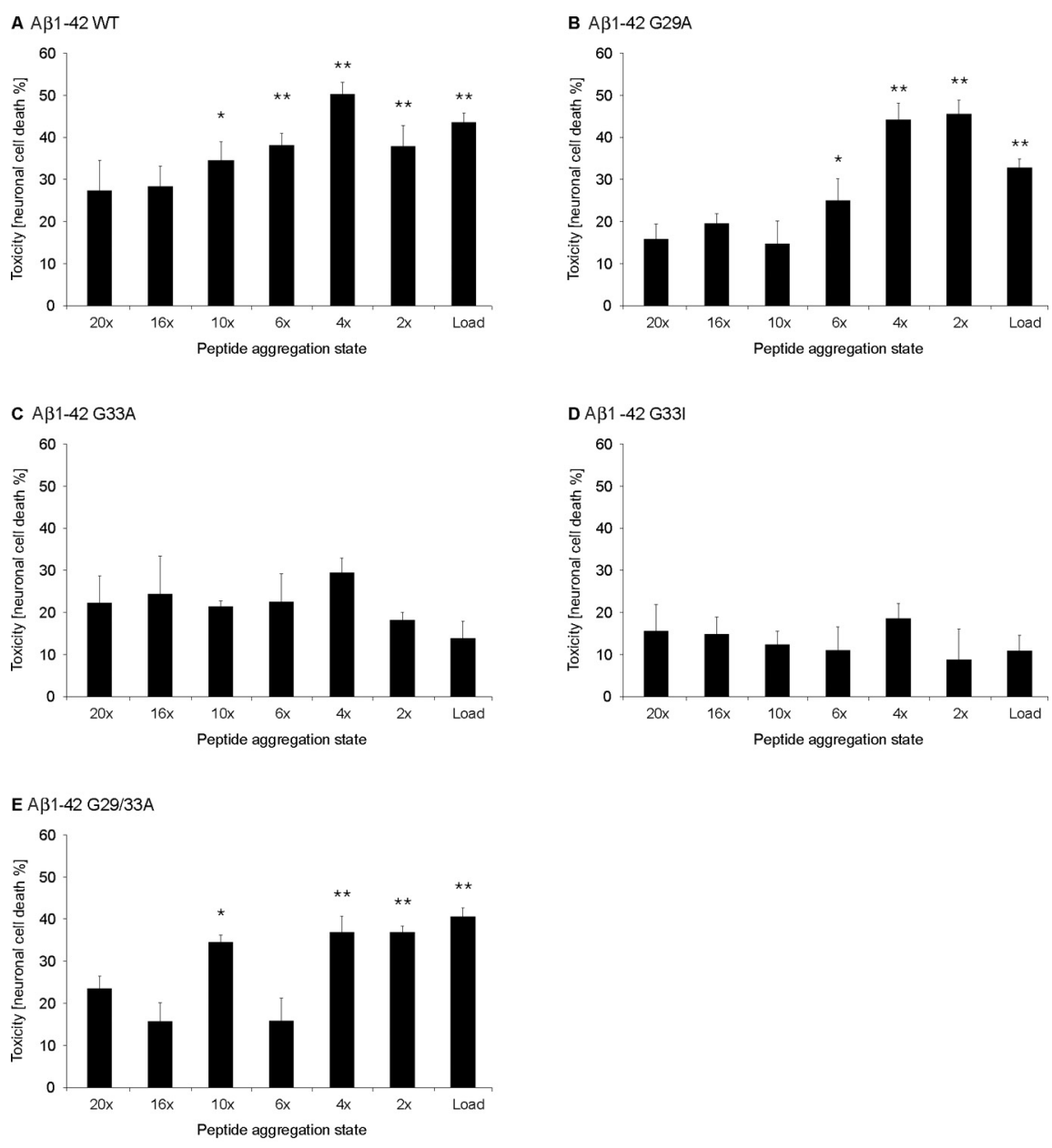

Figure 5. $A \beta_{42}$ WT but not $A \beta_{42}$ G33 substitution peptides are toxic to primary neurons. Measurements were performed with neurons incubated with equal amounts of freshly dissolved synthetic peptides (Load) or SEC fractions. Results are expressed as percentage of cell death. $A, A \beta_{42}$ WT ( $n=4-8 \pm$ SEM) induces a maximal toxicity. Comparable with the data generated from neuroblastoma cells, toxicity increases from monomeric to tetrameric forms and then gradually decreases again as the peptide aggregates further into higher oligomers up to 20 -mers. $B$, Similar to $A \beta_{42}$ WT, the same pattern could be observed for $A \beta_{42} G 29 A$ $\left(n=2-8 \pm\right.$ SEM). C, $\boldsymbol{D}, A \beta_{42} \mathrm{G} 33 \mathrm{~A}(\boldsymbol{C})$ and $\mathrm{A} \beta_{42} \mathrm{G} 33 \mathrm{I}(\boldsymbol{D})(n=4-8 \pm$ SEM) cause no significant toxicity in primary neurons. $\boldsymbol{E}$, Toxicity of $A \beta_{42} \mathrm{G} 29 / 33 \mathrm{~A}\left(n=2-8 \pm \mathrm{SEM}\right.$ ) is similar to $A \beta_{42}$ WT for monomers to tetramers and to $A \beta_{42} \mathrm{G} 33$ variant peptides for higher aggregates. A one-way ANOVA using Dunnett's multiple comparison test comparing peptides with untreated control was performed $\left({ }^{*} p<0.001,{ }^{* *} p<0.0001\right)$.

nal cultures and in the Drosophila melanogaster eye and the inhibition of LTP. Furthermore, we have investigated in detail the importance of the GxxxG motif for $A \beta$ aggregation and toxicity and the interrelationship between toxicity and LTP inhibition as well as conformational characteristics of $\mathrm{A} \beta$ oligomers by using limited tryptic proteolysis in combination with computational modeling.

Early oligomerization has been regarded as the most important prerequisite for $A \beta$ peptides to gain toxicity. In the case of $\mathrm{A} \beta_{42} \mathrm{G} 33$ substitution peptides, oligomerization was neither sufficient to induce toxic effects nor to inhibit LTP, and therefore, oligomer formation and toxicity of $\mathrm{A} \beta$ are unlinked. Our results obtained by SEC and Western blot analysis exhibited that $\mathrm{A} \beta_{42}$ G33 substitution peptides immediately formed higher oligomers compared with $\mathrm{A} \beta_{42}$ WT. Data achieved from limited proteolysis emphasizes that G33 variants have a more compact folding core. These results were supported by computational modeling, which indicates that the effective shielding of hydrophobic side chains from the polar milieu promotes a tight folding of the peptides and even more their formation into higher oligomers as analyzed by SEC. Consistently, only residual amounts of dimers and tetramers generated under native conditions and no SDS-resistant low- $n$ oligomers could be detected in case of G33I. Since the G29A substitution in the turn region of $A \beta$ is entirely exposed to the solvent, modeling data suggested that the core is destabilized without affecting the aggregation behavior. The folding nucleus of G29A is less compact, and the accessibility for trypsin at the cleavage site $\mathrm{K} 28$ as part of the core is increased. When combining both substitutions to $A \beta_{42}$ G29/33A, an intermediate behavior was observed in terms of peptide oligomerization with an intermediate distribution between low- $n$ and high- $n$ oligomers. Thus, a specific conformation is maintained by the GxxxG sequence in the C-terminal half of $A \beta$, which is required for its toxicity. This is in agreement with toxicity studies using G33L substitutions of $A \beta$ that showed a reduced formation of dimers and trimers by mass spectrometry analysis (Hung et al., 2008). Biophysical characterization of the so-called GSL (glycine substitution to leucine) peptides revealed an increased rate of fibril formation and a reduced ability to bind to lipid membranes (Hung et al., 2008). Also, the in vitro toxicity of GSL substitutions peptides was suggested to depend on their ability to disrupt membranes (Kim et al., 2005).

In accordance with other studies where soluble lower- $n$ oligomers were identified to be responsible for $\mathrm{A} \beta$ toxicity (Yankner et al., 1989; Stern et al., 2004; Shankar et al., 2008), we depicted $\mathrm{A} \beta_{42}$ WT tetramers as the most toxic form for neuroblastoma cells and for primary hippocampal neurons. The extent of cell loss decreased with increasing grade of oligomerization of $\mathrm{A} \beta_{42}$ WT or $\mathrm{A} \beta_{42}$ G29A peptides. In sharp contrast, none of the peptides $A \beta_{42}$ G33A or G33I were toxic, neither to neuroblastoma cells nor to primary hippocampal neurons. Although $\mathrm{A} \beta_{42}$ WT tetramers were highly toxic, the tetramers of $\mathrm{A} \beta_{42}$ G33 variants were nontoxic and thereby provided evidence that the aggregation of $\mathrm{A} \beta_{42}$ peptides is uncoupled from toxicity. Complementary to the intermediate position in its aggregation behavior, the $A \beta_{42}$ G29/33A peptide revealed an inbetween toxicity of $\mathrm{A} \beta_{42}$ WT and G33 substitutions. Although synthetic peptides did not allow to directly assess whether cellderived $\mathrm{A} \beta$ can have similar effects, we generated Drosophila melanogaster models expressing secreted $\mathrm{A} \beta_{42}$ WT and G33 variants in the eye. The results are in agreement with the cell-culture data insofar as Drosophila eyes expressing $\mathrm{A} \beta_{42}$ G33I are normal compared with $\mathrm{A} \beta_{42}$ WT expressing flies, although the aggregation state in the eyes remains unclear.

Since diffusible oligomers of $A \beta$ initiate a synaptic dysfunction that is believed to be an early event in AD (Walsh et al., 2002; Cleary et al., 2005), we performed field recordings in hippocampal slices with $A \beta$ G33 variants to test if these peptides inhibit 
synaptic plasticity. Although $\mathrm{A} \beta_{42}$ WT entirely inhibited LTP, $\mathrm{A} \beta_{42}$ G33I and particularly $\mathrm{A} \beta_{42}$ G33A tetramers showed an attenuated LTP inhibition. Thus, $\mathrm{A} \beta_{42} \mathrm{WT}$ impairs synaptic plasticity, whereas G33 variants are inert. This is in full agreement with the current knowledge on $\mathrm{A} \beta \mathrm{WT}$ toxicity and implies the existence of a molecular link between peptide toxicity and a specific conformation of $A \beta$ oligomers.

In conclusion, G33 substitutions could uncouple oligomerization from toxicity and LTP inhibition. The nonpathogenic effects of these substitutions can be mechanistically accounted for by fold stabilization. We propose that by enhancing the hydrophobicity at position G33 $\mathrm{A} \beta_{42}$ aggregation is alleviated, and the aggregates-because of the tertiary structure they adopt-neither impair cell viability nor inhibit synaptic plasticity. On the background that hydrophobic stretches in the C-terminal half of $\mathrm{A} \beta_{42}$ are sufficient to promote aggregation (Kim and Hecht, 2006), our data underline the importance of the GxxxG motif for the specific toxic $\mathrm{A} \beta$ fold. Beyond soluble oligomers that are intermediates in the fibrillization process, substitutions of G29, G33, and G37 of the GxxxG motif were described as generally destabilizing for fibril structures (Morimoto et al., 2004; Williams et al., 2004; Shivaprasad and Wetzel, 2006; Williams et al., 2006).

Our results suggest the existence of different types of $\mathrm{A} \beta_{42}$ strains, some causing toxic effects and others aggregation into oligomers without adopting toxic conformations. This hypothesis is supported by the effects of $A \beta_{42}$ G29/33A oligomers, which might represent transition forms of a mixture of toxic and nontoxic amyloid strains. Regarding the mechanism of toxicity caused by $\mathrm{A} \beta$, the cellular prion protein and the amyloid precursor-like protein 1 (APLP1) were suggested as possible mediators of $A \beta$-induced synaptic dysfunction (Laurén et al., 2009). APLP1 forms heterodimers with APP and is mainly present on the cell surface (Kaden et al., 2009); it is, therefore, a strong candidate receptor for $\mathrm{A} \beta$ oligomers.

The findings of our study now open up a new avenue to analyze the binding of nontoxic and toxic oligomers to the proposed receptors and to unravel the mechanisms of $\mathrm{A} \beta$ toxicity in more detail to combat disease causes in $\mathrm{AD}$.

\section{References}

Baker NA, Sept D, Joseph S, Holst MJ, McCammon JA (2001) Electrostatics of nanosystems: application to microtubules and the ribosome. Proc Natl Acad Sci U S A 98:10037-10041.

Basler K, Hafen E (1988) Sevenless and Drosophila eye development: a tyrosine kinase controls cell fate. Trends Genet 4:74-79.

Beyermann M, Fechner K, Furkert J, Krause E, Bienert M (1996) A singlepoint slight alteration set as a tool for structure-activity relationship studies of ovine corticotropin releasing factor. J Med Chem 39:3324-3330.

Bucciantini M, Giannoni E, Chiti F, Baroni F, Formigli L, Zurdo J, Taddei N, Ramponi G, Dobson CM, Stefani M (2002) Inherent toxicity of aggregates implies a common mechanism for protein misfolding diseases. Nature 416:507-511.
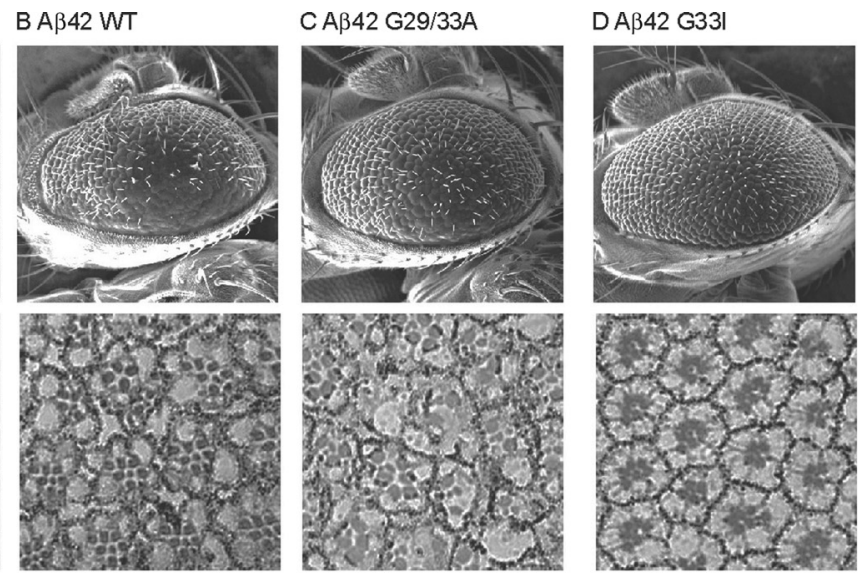

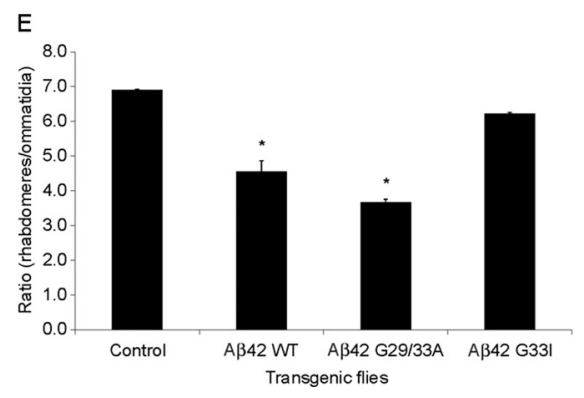

Figure 6. $A \beta_{42}$ WT but not $A \beta_{42}$ G33 mutants are toxic in vivo in transgenic Drosophila melanogaster expressing extracellular $\beta_{42}$ WT or mutant peptides. For the analyses, strains of flies were selected for expressing equal amounts of $A \beta$ forms (supple-

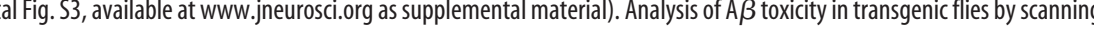
tio between rhabdomeres and ommatidia in $3-5$ animals for each group. Both $A \beta_{42}$ WT and G29/33A expressing flies are highly toxic compared with nontransgenic control flies, whereas $A \beta_{42} \mathrm{G} 33 \mathrm{I}$ does not cause severe eye damage. Student's $t$ test was used

Cheon M, Chang I, Mohanty S, Luheshi LM, Dobson CM, Vendruscolo M, Favrin G (2007) Structural reorganisation and potential toxicity of oligomeric species formed during the assembly of amyloid fibrils. PLoS Comput Biol 3:1727-1738.

Christen M, Hünenberger PH, Bakowies D, Baron R, Bürgi R, Geerke DP, Heinz TN, Kastenholz MA, Kräutler V, Oostenbrink C, Peter C, Trzesniak D, van Gunsteren WF (2005) The GROMOS software for biomolecular simulation: GROMOS05. J Comput Chem 26:1719-1751.

Cleary JP, Walsh DM, Hofmeister JJ, Shankar GM, Kuskowski MA, Selkoe DJ, Ashe KH (2005) Natural oligomers of the amyloid-beta protein specifically disrupt cognitive function. Nat Neurosci 8:79-84.

Finelli A, Kelkar A, Song HJ, Yang H, Konsolaki M (2004) A model for studying Alzheimer's Abeta42-induced toxicity in Drosophila melanogaster. Mol Cell Neurosci 26:365-375.

Freir DB, Costello DA, Herron CE (2003) A beta 25-35-induced depression of long-term potentiation in area CA1 in vivo and in vitro is attenuated by verapamil. J Neurophysiol 89:3061-3069.

Gengler S, Gault VA, Harriott P, Hölscher C (2007) Impairments of hippocampal synaptic plasticity induced by aggregated beta-amyloid (25-35) are dependent on stimulation-protocol and genetic background. Exp Brain Res 179:621-630.

Gong Y, Chang L, Viola KL, Lacor PN, Lambert MP, Finch CE, Krafft GA, Klein WL (2003) Alzheimer's disease-affected brain: presence of oligomeric A beta ligands (ADDLs) suggests a molecular basis for reversible memory loss. Proc Natl Acad Sci U S A 100:10417-10422.

Grant MA, Lazo ND, Lomakin A, Condron MM, Arai H, Yamin G, Rigby AC, Teplow DB (2007) Familial Alzheimer's disease mutations alter the stability of the amyloid beta-protein monomer folding nucleus. Proc Natl Acad Sci U S A 104:16522-16527.

Hsia AY, Masliah E, McConlogue L, Yu GQ, Tatsuno G, Hu K, Kholodenko 

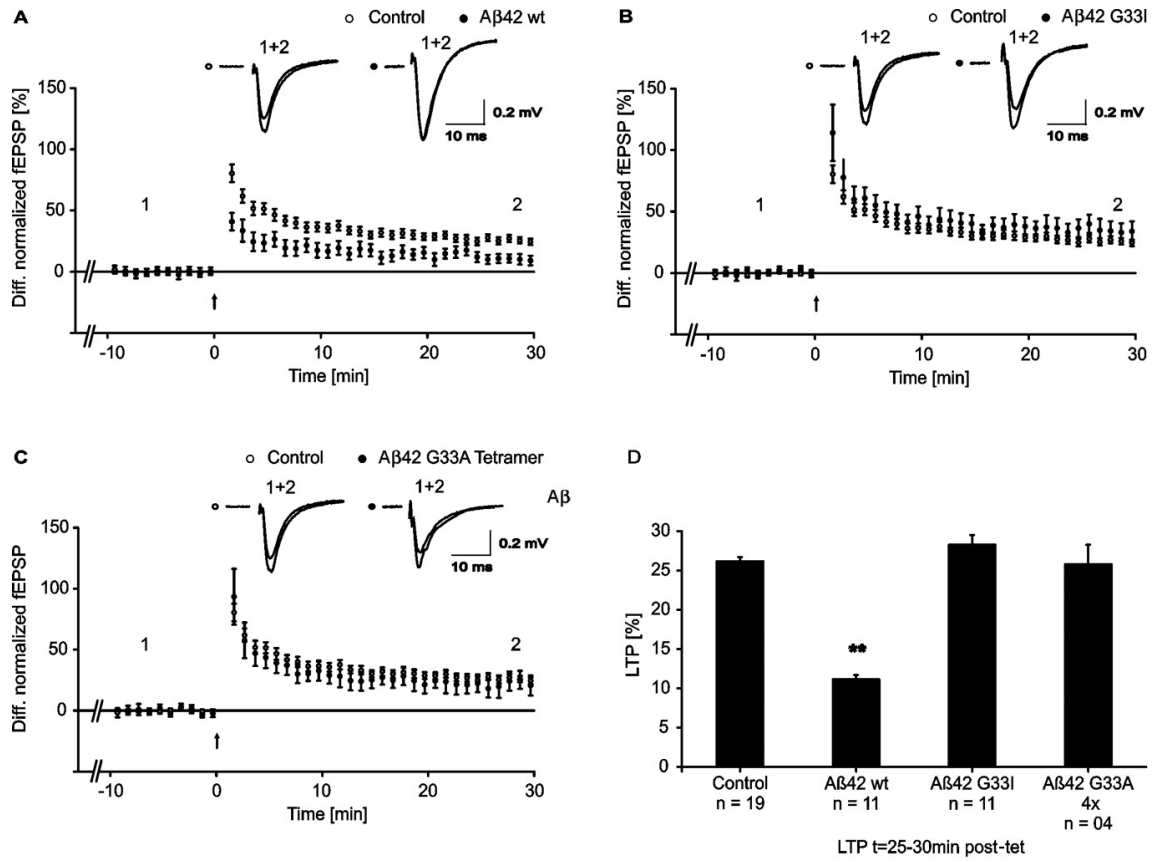

Figure 7. LTP of $S$ chaffer collateral CA1 region is inhibited by $A \beta_{42}$ WT but not $A \beta_{42}$ G33 substitution peptides. LTP induction with theta-burst stimulation is marked by an arrow. Peptide $(500 \mathrm{~nm})$ was washed-in for 20 min before tetanization, no wash-out occurred during the whole experiment. $\boldsymbol{A}-\boldsymbol{C}$ represents fEPSP difference of unstimulated control pathway and stimulated pathway. Insets show average baseline (1) and post-TBS (2) fEPSP traces with calibration bars: $10 \mathrm{~ms}, 0.2 \mathrm{mV}$. A $\beta_{42}$ peptides (closed circles) in overlay with control measurements (open circles). Incubation with $A \beta_{42}$ WT $(A)$ peptide leads to LTP inhibition, whereas $A \beta_{42} G 33$ ( $B$ ) does not inhibit LTP. $C$, Nontoxic $A \beta_{42}$ G33A tetramer peptide does not inhibit LTP. D, Quantification of $25-30$ min post-tetanus of each measurement (control, $n=19 \pm$ SEM; $A \beta_{42}$ WT/G33I, $n=11 \pm$ SEM; $A \beta_{42}$ G33A, $n=4 \pm$ SEM). A one-way ANOVA using Dunnett's multiple comparison test comparing peptides with untreated control was performed $\left({ }^{*} p<\right.$ $\left.0.01,{ }^{* *} p<0.001\right)$.

D, Malenka RC, Nicoll RA, Mucke L (1999) Plaque-independent disruption of neural circuits in Alzheimer's disease mouse models. Proc Natl Acad Sci U S A 96:3228-3233.

Hsieh H, Boehm J, Sato C, Iwatsubo T, Tomita T, Sisodia S, Malinow R (2006) AMPAR removal underlies Abeta-induced synaptic depression and dendritic spine loss. Neuron 52:831-843.

Hung LW, Ciccotosto GD, Giannakis E, Tew DJ, Perez K, Masters CL, Cappai $\mathrm{R}$, Wade JD, Barnham KJ (2008) Amyloid- $\beta$ peptide $(\mathrm{A} \beta$ ) neurotoxicity is modulated by the rate of peptide aggregation: $\mathrm{A} \beta$ dimers and trimers correlate with neurotoxicity. J Neurosci 28:11950-11958.

Jarrett JT, Lansbury PT Jr (1993) Seeding "one-dimensional crystallization" of amyloid: a pathogenic mechanism in Alzheimer's disease and scrapie? Cell 73:1055-1058.

Kaden D, Munter LM, Joshi M, Treiber C, Weise C, Bethge T, Voigt P, Schaefer M, Beyermann M, Reif B, Multhaup G (2008) Homophilic interactions of the amyloid precursor protein (APP) ectodomain are regulated by the loop region and affect beta-secretase cleavage of APP. J Biol Chem 283:7271-7279.

Kaden D, Voigt P, Munter LM, Bobowski KD, Schaefer M, Multhaup G (2009) Subcellular localization and dimerization of APLP1 are strikingly different from APP and APLP2. J Cell Sci 122:368-377.

Kayed R, Head E, Thompson JL, McIntire TM, Milton SC, Cotman CW, Glabe CG (2003) Common structure of soluble amyloid oligomers implies common mechanism of pathogenesis. Science 300:486-489.

Kienlen-Campard P, Tasiaux B, Van Hees J, Li M, Huysseune S, Sato T, Fei JZ, Aimoto S, Courtoy PJ, Smith SO, Constantinescu SN, Octave JN (2008) Amyloidogenic processing but not amyloid precursor protein (APP) intracellular C-terminal domain production requires a precisely oriented APP dimer assembled by transmembrane GXXXG motifs. J Biol Chem 283:7733-7744.

Kim S, Jeon TJ, Oberai A, Yang D, Schmidt JJ, Bowie JU (2005) Transmembrane glycine zippers: physiological and pathological roles in membrane proteins. Proc Natl Acad Sci U S A 102:14278-14283.

Kim W, Hecht MH (2006) Generic hydrophobic residues are sufficient to promote aggregation of the Alzheimer's Abeta42 peptide. Proc Natl Acad Sci U S A 103:15824-15829.

Klyubin I, Walsh DM, Lemere CA, Cullen WK, Shankar GM, Betts V, Spooner ET, Jiang L, Anwyl R, Selkoe DJ, Rowan MJ (2005) Amyloid beta protein immunotherapy neutralizes Abeta oligomers that disrupt synaptic plasticity in vivo. Nat Med 11:556-561.

Klyubin I, Betts V, Welzel AT, Blennow K, Zetterberg $\mathrm{H}$, Wallin A, Lemere CA, Cullen WK, Peng Y, Wisniewski T, Selkoe DJ, Anwyl R, Walsh DM, Rowan MJ (2008) Amyloid $\beta$ protein dimer-containing human CSF disrupts synaptic plasticity: prevention by systemic passive immunization. J Neurosci 28:4231-4237.

Laurén J, Gimbel DA, Nygaard HB, Gilbert JW, Strittmatter SM (2009) Cellular prion protein mediates impairment of synaptic plasticity by amyloid-beta oligomers. Nature 457:1128-1132.

Lazo ND, Grant MA, Condron MC, Rigby AC, Teplow DB (2005) On the nucleation of amyloid beta-protein monomer folding. Protein Sci 14:1581-1596.

Liu W, Crocker E, Zhang W, Elliott JI, Luy B, Li H, Aimoto S, Smith SO (2005) Structural role of glycine in amyloid fibrils formed from transmembrane alpha-helices. Biochemistry 44:3591-3597.

Lührs T, Ritter C, Adrian M, Riek-Loher D, Bohrmann B, Döbeli H, Schubert D, Riek R (2005) 3D structure of Alzheimer's amyloid-beta(142) fibrils. Proc Natl Acad Sci USA 102:17342-17347.

Martins IC, Kuperstein I, Wilkinson H, Maes E, Vanbrabant M, Jonckheere W, Van Gelder P, Hartmann D, D'Hooge R, De Strooper B, Schymkowitz J, Rousseau F (2008) Lipids revert inert Abeta amyloid fibrils to neurotoxic protofibrils that affect learning in mice. EMBO J 27:224-233.

McLean CA, Cherny RA, Fraser FW, Fuller SJ, Smith MJ, Beyreuther K, Bush AI, Masters CL (1999) Soluble pool of Abeta amyloid as a determinant of severity of neurodegeneration in Alzheimer's disease. Ann Neurol 46:860-866.

Moechars D, Dewachter I, Lorent K, Reversé D, Baekelandt V, Naidu A, Tesseur I, Spittaels K, Haute CV, Checler F, Godaux E, Cordell B, Van Leuven F (1999) Early phenotypic changes in transgenic mice that overexpress different mutants of amyloid precursor protein in brain. J Biol Chem 274:6483-6492.

Morimoto A, Irie K, Murakami K, Masuda Y, Ohigashi H, Nagao M, Fukuda H, Shimizu T, Shirasawa T (2004) Analysis of the secondary structure of beta-amyloid (Abeta42) fibrils by systematic proline replacement. J Biol Chem 279:52781-52788.

Mucke L, Masliah E, Yu GQ, Mallory M, Rockenstein EM, Tatsuno G, Hu K, Kholodenko D, Johnson-Wood K, McConlogue L (2000) High-level neuronal expression of $\mathrm{A} \beta_{1-42}$ in wild-type human amyloid protein precursor transgenic mice: synaptotoxicity without plaque formation. J Neurosci 20:4050-4058.

Munter LM, Voigt P, Harmeier A, Kaden D, Gottschalk KE, Weise C, Pipkorn R, Schaefer M, Langosch D, Multhaup G (2007) GxxxG motifs within the amyloid precursor protein transmembrane sequence are critical for the etiology of Abeta42. EMBO J 26:1702-1712.

Podlisny MB, Ostaszewski BL, Squazzo SL, Koo EH, Rydell RE, Teplow DB, Selkoe DJ (1995) Aggregation of secreted amyloid beta-protein into sodium dodecyl sulfate-stable oligomers in cell culture. J Biol Chem 270:9564-9570

Qi-Takahara Y, Morishima-Kawashima M, Tanimura Y, Dolios G, Hirotani N, Horikoshi Y, Kametani F, Maeda M, Saido TC, Wang R, Ihara Y (2005) Longer forms of amyloid $\beta$ protein: implications for the mechanism of intramembrane cleavage by $\gamma$-secretase. J Neurosci 25:436-445. 
Roher AE, Chaney MO, Kuo YM, Webster SD, Stine WB, Haverkamp LJ, Woods AS, Cotter RJ, Tuohy JM, Krafft GA, Bonnell BS, Emmerling MR (1996) Morphology and toxicity of Abeta-(1-42) dimer derived from neuritic and vascular amyloid deposits of Alzheimer's disease. J Biol Chem 271:20631-20635.

Roher AE, Baudry J, Chaney MO, Kuo YM, Stine WB, Emmerling MR (2000) Oligomerizaiton and fibril asssembly of the amyloid-beta protein. Biochim Biophys Acta 1502:31-43.

Roychaudhuri R, Yang M, Hoshi MM, Teplow DB (2009) Amyloid \{beta protein assembly and alzheimer disease. J Biol Chem 284:4749-4753.

Sanner MF, Olson AJ, Spehner JC (1996) Reduced surface: an efficient way to compute molecular surfaces. Biopolymers 38:305-320.

Sato T, Kienlen-Campard P, Ahmed M, Liu W, Li H, Elliott JI, Aimoto S, Constantinescu SN, Octave JN, Smith SO (2006) Inhibitors of amyloid toxicity based on beta-sheet packing of Abeta40 and Abeta42. Biochemistry 45:5503-5516.

Schmechel A, Zentgraf H, Scheuermann S, Fritz G, Pipkorn R, Reed J, Beyreuther K, Bayer TA, Multhaup G (2003) Alzheimer beta-amyloid homodimers facilitate A beta fibrillization and the generation of conformational antibodies. J Biol Chem 278:35317-35324.

Shankar GM, Bloodgood BL, Townsend M, Walsh DM, Selkoe DJ, Sabatini BL (2007) Natural oligomers of the Alzheimer amyloid- $\beta$ protein induce reversible synapse loss by modulating an NMDA-type glutamate receptor-dependent signaling pathway. J Neurosci 27:2866-2875.

Shankar GM, Li S, Mehta TH, Garcia-Munoz A, Shepardson NE, Smith I, Brett FM, Farrell MA, Rowan MJ, Lemere CA, Regan CM, Walsh DM, Sabatini BL, Selkoe DJ (2008) Amyloid-beta protein dimers isolated directly from Alzheimer's brains impair synaptic plasticity and memory. Nat Med 14:837-842.

Shivaprasad S, Wetzel R (2006) Scanning cysteine mutagenesis analysis of Abeta-(1-40) amyloid fibrils. J Biol Chem 281:993-1000.

Simmons LK, May PC, Tomaselli KJ, Rydel RE, Fuson KS, Brigham EF,
Wright S, Lieberburg I, Becker GW, Brems DN, Li WY (1994) Secondary structure of amyloid beta peptide correlates with neurotoxic activity in vitro. Mol Pharmacol 45:373-379.

Spires TL, Meyer-Luehmann M, Stern EA, McLean PJ, Skoch J, Nguyen PT, Bacskai BJ, Hyman BT (2005) Dendritic spine abnormalities in amyloid precursor protein transgenic mice demonstrated by gene transfer and intravital multiphoton microscopy. J Neurosci 25:7278-7287.

Stern EA, Bacskai BJ, Hickey GA, Attenello FJ, Lombardo JA, Hyman BT (2004) Cortical synaptic integration in vivo is disrupted by amyloid- $\beta$ plaques. J Neurosci 24:4535-4540.

Walsh DM, Klyubin I, Fadeeva JV, Cullen WK, Anwyl R, Wolfe MS, Rowan MJ, Selkoe DJ (2002) Naturally secreted oligomers of amyloid beta protein potently inhibit hippocampal long-term potentiation in vivo. Nature 416:535-539.

Wang HW, Pasternak JF, Kuo H, Ristic H, Lambert MP, Chromy B, Viola KL, Klein WL, Stine WB, Krafft GA, Trommer BL (2002) Soluble oligomers of beta amyloid (1-42) inhibit long-term potentiation but not long-term depression in rat dentate gyrus. Brain Res 924:133-140.

Williams AD, Portelius E, Kheterpal I, Guo JT, Cook KD, Xu Y, Wetzel R (2004) Mapping abeta amyloid fibril secondary structure using scanning proline mutagenesis. J Mol Biol 335:833-842.

Williams AD, Shivaprasad S, Wetzel R (2006) Alanine scanning mutagenesis of Abeta(1-40) amyloid fibril stability. J Mol Biol 357:1283-1294.

Yankner BA, Dawes LR, Fisher S, Villa-Komaroff L, Oster-Granite ML, Neve RL (1989) Neurotoxicity of a fragment of the amyloid precursor associated with Alzheimer's disease. Science 245:417-420.

Younkin SG (1998) The role of A beta 42 in Alzheimer's disease. J Physiol Paris 92:289-292.

Zhao G, Cui MZ, Mao G, Dong Y, Tan J, Sun L, Xu X (2005) gammaCleavage is dependent on zeta-cleavage during the proteolytic processing of amyloid precursor protein within its transmembrane domain. J Biol Chem 280:37689-37697. 